\title{
Tamoxifen exerts agonistic effects on clusterin and complement C3 gene expression in RUCA-I primary xenografts and metastases but not normal uterus
}

\author{
Oliver Zierau, Jacintha O'Sullivan ${ }^{1}$, Colm Morrissey ${ }^{1}$, Dana McDonald ${ }^{1}$, \\ Winfried Wünsche, Martin R Schneider ${ }^{2}$, Martin P Tenniswood ${ }^{1}$ \\ and Günter Vollmer
}

Institute for Zoology, Technische Universität Dresden, Dresden, Germany

${ }^{1}$ Department of Biological Sciences, University of Notre Dame, Indiana 46556, USA

${ }^{2}$ Research Laboratories of Schering AG, Experimental Oncology, Berlin, Germany

(Requests for offprints should be addressed to O Zierau, Molecular Cell Physiology and Endocrinology, Technische Universität Dresden, Mommsenstrasse 13, 01062 Dresden, Germany; Email: oliver.zierau@mailbox.tu-dresden.de)

(W Wünsche is now at Institute for Molecular Medicine, Universität zu Lübeck, Lübeck, Germany)

\begin{abstract}
Tamoxifen is the most widely prescribed anti-neoplastic drug for the treatment of both localized and metastatic breast cancer. It is also the prototype for a class of drugs that are referred to as selective estrogen receptor modifiers (SERMs), most of which have both estrogenic and anti-estrogenic activity in estrogen target tissues including the breast and endometrium. The underlying mechanisms of action of SERMs in the breast and endometrium that lead to profound differences in the tissue-specific effects of tamoxifen have not yet been elucidated.

We have compared the effects of tamoxifen and the pure anti-estrogen ICI 182,780 (Faslodex) in the RUCA-I hormone-responsive rat endometrial cell line in vitro and in vivo. In cell culture, RUCA-I cells responded to both estrogens and anti-estrogens, and the expression of clusterin and complement C3 mRNAs required the presence of estradiol and was repressed in the absence of estradiol or in the presence of the pure anti-estrogen $\mathrm{ICI}$ 182,780. Tamoxifen, on the other hand, induced both complement $\mathrm{C} 3$ and clusterin mRNA in the absence of estradiol and failed to repress their expression in the presence of estradiol. When grown as subcutaneous xenografts in syngeneic Da/Han rats for 5 weeks, the RUCA-I cells retained their sensitivity to estradiol, as demonstrated by significantly enhanced tumor growth in intact female rats compared with the growth in ovariectomized rats. But neither ICI 182,780 nor tamoxifen had a significant impact on tumor growth in cycling or ovariectomized animals. On the other hand, tamoxifen was potently estrogenic in metastatic lymph nodes, increasing the size of the lymph node tumors almost 6-fold over that seen in the intact cycling animals. In primary tumors, the expression of complement $\mathrm{C} 3$ mirrored that seen in vitro, although tamoxifen showed some agonist activity in ovariectomized animals. Tamoxifen also displayed marked agonist activity with respect to clusterin expression and enhanced clusterin mRNA levels and protein in both the primary tumors and lymph metastases in intact and ovariectomized animals.

Given the recent demonstration that over-expression of clusterin increases the metastatic potential of breast cancer cells, these data may provide a mechanistic explanation for the increased incidence of endometrial cancer in postmenopausal patients treated with tamoxifen.
\end{abstract}

Endocrine-Related Cancer (2004) 11 823-830 


\section{Introduction}

The endometrium is a major target organ of the ovarian sex steroid hormones, estradiol and progesterone, which mediate diverse physiological functions via interaction with their cognate nuclear receptors (Flototto et al. 2001). Probably the most important influence of estradiol in the endometrium is stimulation of cell proliferation. The unopposed action of estrogen appears to increase the risk of precancerous endometrial lesions and malignant carcinoma in rodents (Lupulescu 1993, 1995) and humans (The Practice Committee of the American Society for Reproductive Medicine 2004), and endometrial carcinoma is the most common gynecologic malignancy in industrialized countries (Salvesen \& Akslen 2002). Recent studies have noted a small but significant increase in the incidence of endometrial cancer in postmenopausal women using hormonal replacement therapy (Chlebowski et al. 2002), and there is also an increased risk of endometrial cancer, particularly in postmenopausal women treated with selective estrogen receptor modifiers (SERMs) such as tamoxifen in a chemopreventive setting for breast cancer (Chlebowski et al. 2002).

To examine this hypothesis we have compared the biological action of estradiol, tamoxifen (the prototype SERM) and the pure anti-estrogen ICI 182,780 (Faslodex) in RUCA-I cells in vitro, and in the RUCA-I xenograft model of endometrial carcinoma (Schutze et al. 1992, Vollmer \& Schneider 1996). This cell line expresses estrogen receptor- $\alpha$ (ER- $\alpha$ ) (Vollmer \& Schneider 1996) and, when cultured on an appropriate extracellular matrix or grown as a xenograft, the RUCA-I cell line is an excellent model to study hormone-dependent processes in endometrial tumor progression and metastasis (Wunsche et al. 1998).

When grown as a subcutaneous xenograft, RUCA-I tumors display a moderately high differentiated phenotype, are ER- $\alpha$ positive (Vollmer \& Schneider 1996), and the expression of complement $\mathrm{C} 3$ and clusterin is responsive to estrogens, phytoestrogens and anti-estrogens (Wunsche et al. 1998, Heikaus et al. 2002). We have examined the effects of tamoxifen and ICI 182,780 on the uterus and RUCA-I tumor xenografts in cycling females, ovariectomized and estradiol-supplemented female syngeneic $\mathrm{Da} / \mathrm{Han}$ rats, using organ weight and expression of complement $\mathrm{C} 3$ and clusterin as endpoints. The data demonstrated that, in contrast to ICI 182,780 which only displays antagonist activity in the uterus, primary tumor and metastases, tamoxifen, depending on the setting, acts as an agonist or antagonist in the uterus and as a strong agonist in the metastatic deposits in the lymph nodes, significantly stimulating the expression of complement $\mathrm{C} 3$ in the primary tumor and clusterin in both the primary tumor and lymph nodes. Recent findings link clusterin over-expression to the initiation of the metastatic cascade. Taking these data into consideration, the findings may have significant implications for the use of tamoxifen in a chemopreventive setting and in breast cancer treatment, for the risk of development of uterine cancer.

\section{Materials and Methods Hormones}

17 $\beta$-Estradiol, tamoxifen and 4-OH-tamoxifen were obtained from Sigma (Deissenhofen, Germany) and ICI 182,780 (Faslodex) was synthesized by Schering (Berlin, Germany).

\section{Cell culture}

RUCA-I cells (from frozen stocks of passage 24) were cultured for one passage in Dulbecco's minimum Eagle's medium (DMEM)/F12 medium without phenol red containing $10 \%$ fetal calf serum (FCS), and for two passages in the same medium containing 5\% dextrancoated charcoal treated FCS. For routine experiments, $2.5-3.0 \times 10^{5}$ cells were seeded on $250 \mu$ ECM substrate (Harbour matrix; Cell Systems, Remagen, Germany) per well of a 24-well plate in the presence of $2 \mathrm{ml}$ serum-free defined medium (DMEM/F12 supplemented with $2 \mu \mathrm{g} / \mathrm{ml}$ insulin, $4 \mathrm{mM}$ glutamine, $40 \mu \mathrm{g} / \mathrm{ml}$ transferin, $10^{-8} \mathrm{M}$ hydrocortisone, $2 \times 10^{-8} \mathrm{M}$ sodium selenite and $1 \mu \mathrm{g} / \mathrm{ml}$ putrescine). The cells were maintained in a humidified $5 \% \mathrm{CO}^{2}$ atmosphere at $37^{\circ} \mathrm{C}$ and medium was changed daily.

\section{Hormonal treatment of RUCA-I cells in vitro}

Prior to hormonal treatment, 2.5-3.0 × 10 5 RUCA-I cells were seeded on $250 \mu \mathrm{l}$ extracellular matrix (ECM) substrate and cultured in serum-free defined medium for 2-48 $\mathrm{h}$ with $10^{-7} \mathrm{M}$ estradiol in the absence or presence of $5 \times 10^{-7} \mathrm{M}$ ICI 182,780 or $10^{-6} \mathrm{M} 4-\mathrm{OH}$-tamoxifen. These concentrations were chosen to ensure that the estrogen and anti-estrogens were present in approximately equipotent concentrations based on their relative binding affinities to the estrogen receptor (Wakeling et al. 1991) and the same as in previous experiments (Wunsche et al. 1998). Control cultures were treated with ethanol as a vehicle control. Medium was changed, and the hormonal treatments were repeated daily.

\section{In vivo growth of RUCA-I cells}

RUCA-I cells (from frozen stocks of passage 24) were cultured for one passage on plastic in DMEM/F12 medium without phenol red containing $10 \%$ FCS, and 
harvested by trypsinization. Seven- to eight-week-old female DA/Han rats were ovariectomized under ether anesthesia $48 \mathrm{~h}$ prior to subcutaneous inoculation of $10^{6}$ RUCA-I cells into the right flank. The effective dosages of the (anti-)hormones were the same as in previous experiments (Wunsche et al. 1998). The animals were randomized into five groups of five animals: untreated control females; ovariectomized females; ovariectomized females receiving a single depot injection of estradiol undecyclate $(50 \mu \mathrm{g} /$ rat in $100 \mu \mathrm{l}$; Progynon Depot 100; Schering), a dose known to stimulate EnDA tumour growth in ovariectomized DA/Han rats for at least 5 weeks (Horn et al. 1994); intact females receiving $5 \mathrm{mg} / \mathrm{kg}$ per day ICI 182,780 dissolved in $20 \%$ benzyl benzoate in castor oil; and intact females receiving $20 \mathrm{mg} / \mathrm{kg}$ per day tamoxifen dissolved in $20 \%$ benzyl benzoate in castor oil. The anti-estrogens were administered 6 days a week starting 1 day after tumor cell injection. Tumor growth was monitored weekly by caliper measurement. After 30 days, the animals were killed and the tumors, ipsilateral lymph nodes and uteri were excised and the wet weights were determined. In the control group, cycling animals were selected at random and not at specific times during the estrous cycle. The statistical analysis of tumor and tissue wet weights was performed using Student's $t$-test. All animal handling and experimental conditions were according to the Institutional Animal Care and Use Committee guidelines, regulated by the German federal law for animal welfare.

\section{RNA preparation and Northern blot hybridization}

Total RNA was extracted from tissues (200-500 mg) following pulverization in liquid nitrogen or from cell cultures using guanidinium isothiocyanate and centrifugation through cesium chloride gradients (Chirgwin et al. 1979). Following quantification of the RNA concentration by u.v. light absorption at $280 \mathrm{~nm}$, total RNA (10$20 \mu \mathrm{g}$ ) was electrophoresed on $2.2 \mathrm{M}$ formaldehyde gels and transferred to nylon membranes by vacuum blotting (Pharmacia, Freiburg, Germany). The membranes were prehybridized in Express-Hyb (Clontech/BD, Franklin Lakes, NJ, USA) for $30 \mathrm{~min}$ at $42^{\circ} \mathrm{C}$, hybridized overnight in the same buffer at $42^{\circ} \mathrm{C}$ with $1-1.5 \times 10^{6}$ c.p.m. $/ \mathrm{ml}$ ${ }^{32} \mathrm{P}$-labeled clusterin cDNA or complement C3 cDNA as previously described (Wunsche et al. 1998). The membranes were washed twice in $3 \times \mathrm{SSC}$ transfer buffer $/ 0.1 \%$ $\mathrm{SDS}$ at $25^{\circ} \mathrm{C}$ for $20 \mathrm{~min}$ followed by one wash in $0.5 \times \mathrm{SSC}$ transfer buffer $/ 0.1 \% \mathrm{SDS}$ at $50^{\circ} \mathrm{C}$ for $20 \mathrm{~min}$ and exposed for $24-48$ h to Kodak X-Omat film (Eastman Kodak Co., Rochester, NY, USA) between intensifying screens. The stripped membranes were rehybridized at $42^{\circ} \mathrm{C}$ with a ${ }^{32} \mathrm{P}$-labeled control probe detecting $18 \mathrm{~S}$ ribosomal RNA.

\section{Protein preparation and Western blot analysis}

Tissues (200-500 mg) were pulverized in liquid nitrogen and lyzed in cell lysis buffer $(50 \mathrm{mM}$ Tris- $\mathrm{HCl}, \mathrm{pH} 7.4$, $1 \%$ NP-40, $0.25 \%$ sodium deoxycholate, $150 \mathrm{mM} \mathrm{NaCl}$, $1 \mathrm{mM}$ EGTA, $1 \mathrm{mM}$ phenylmethylsulfonyl fluoride, $1 \mu \mathrm{g} /$ $\mathrm{ml}$ aprotinin, leupeptin, pepstatin, $1 \mathrm{mM} \mathrm{Na} \mathrm{VO}_{4}$ and $1 \mathrm{mM} \mathrm{NaF}$ ). Protein concentrations were determined using bicinchoninic acid (Pierce Chemical Co., Rockford, IL, USA). Equal amounts of protein samples were loaded onto to a $10 \%$ SDS-polyacrylamide gel, electrophoresed and transferred to $0.2 \mu \mathrm{m}$ nitrocellulose membranes (BioRad Laboratories Inc., Richmond, CA, USA). The nitrocellulose membranes were blocked with bovine serum albumin and incubated with 1:10 isoform-specific anti-clusterin monoclonal antibodies (Upstate Biotech, Lake Placid, NY, USA) at room temperature for $1-3 \mathrm{~h}$, followed by incubation with 1:5000 anti-mouse horseradish-peroxidase (HRPO)-conjugated secondary antibodies (Dianova, Hamburg, Germany) at room temperature for $1 \mathrm{~h}$. The Western blots were developed with an enhanced chemiluminescent kit (Amersham International plc, Amersham, Bucks, UK) and exposed to X-Omat AR film at room temperature.

\section{Results}

\section{Effect of estradiol, ICI 182,780 and $4-\mathrm{OH}-$ tamoxifen on steady state levels of complement $\mathrm{C} 3$ and clusterin mRNAs in vitro}

When grown on an appropriate extracellular matrix, RUCA-I cells were responsive to estrogens, and the expression of complement C3 (Fig. 1A) and clusterin (Fig. 1B) displays an absolute requirement for estradiol. In the absence of estradiol, the pure anti-estrogen ICI 182,780 did not induce the expression of either complement $\mathrm{C} 3$ or clusterin mRNA. 4-OH-tamoxifen, on the other hand, showed significant estrogenic activity in the absence of estradiol, up-regulating the steady state levels of both mRNAs. When co-incubated with estradiol, ICI 182,780 effectively blocked the induction of both complement $\mathrm{C} 3$ and clusterin, while 4-OH-tamoxifen had little or no effect on the estrogenic induction of complement $\mathrm{C} 3$ or clusterin mRNAs. These data clearly demonstrated that both complement $\mathrm{C} 3$ and clusterin are responsive to estradiol in vitro and the transcription of these genes can be inhibited by the pure anti-estrogen ICI 182,780 but not the SERM 4-OH-tamoxifen.

\section{Effect of estradiol, ICI 182,780 and tamoxifen on uterine and tumor wet weight in vivo}

In the uterus, tamoxifen displayed antagonist activity and reduced uterine weight in cycling animals almost as 


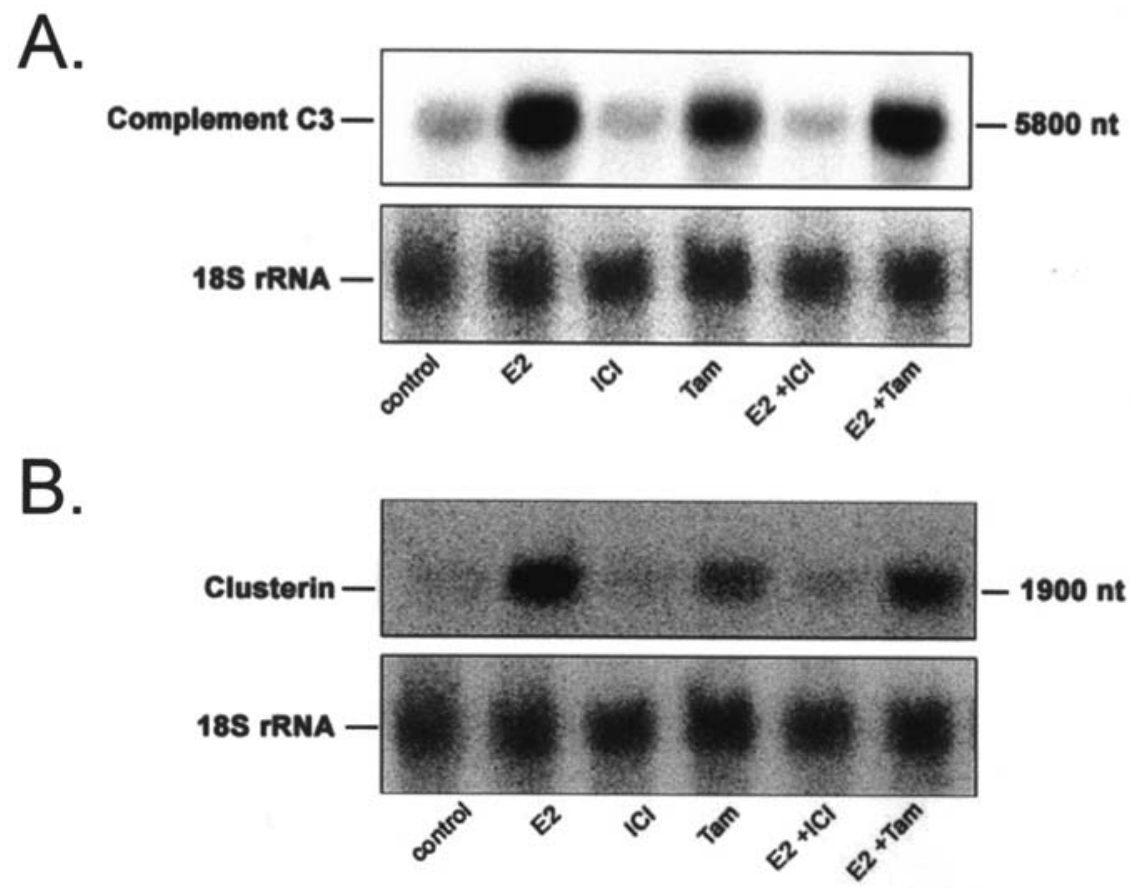

Figure 1 Effect of estradiol, ICl 182,780 and 4-OH tamoxifen on the steady state levels of (A) complement $\mathrm{C} 3$ and (B) clusterin mRNA in RUCA-I cells in vitro. RUCA-I cells were cultured as described in Materials and Methods, and treated for $48 \mathrm{~h}$ with the indicated combination of estrogen (E2) and anti-estrogen. ICI, ICI 182,780; Tam, tamoxifen.

efficiently as either ovariectomy or treatment with ICI 182,780 (Fig. 2A). On the other hand, administration of tamoxifen to ovariectomized animals did stimulate uterine growth.

When grown as subcutaneous tumors in cycling female syngeneic Da/Han rats, RUCA-I form moderately well differentiated tumor cells averaging $790 \mathrm{mg}$ after 30 days. These tumors did not grow as well as in ovariectomized females, averaging $600 \mathrm{mg}$ after 30 days, but did respond significantly to estradiol, reaching an average size of $1150 \mathrm{mg}$ at the time of death. Neither ICI 182,780 nor tamoxifen had a significant impact on tumor growth in cycling animals; however, tamoxifen did not demonstrate any significant agonist activity in ovariectomized animals since it did not stimulate the growth of the tumors in ovariectomized animals (Fig. 2B). This contrasts markedly with the effect of tamoxifen on the growth of the metastatic tumors in the ipsilateral lymph nodes. These metastatic deposits reached a size of approximately $110 \mathrm{mg}$ in cycling animals, and were very responsive to estradiol, averaging $475 \mathrm{mg}$ after 30 days, and were significantly repressed by ovariectomy or ICI 182,780 . Tamoxifen, on the other hand, showed very strong agonist activity in these secondary tumors, stimulating the growth of the tumors by 4 - to 6 -fold, in cycling or ovariectomized animals respectively (Fig. 2C).

\section{Effect of estradiol, ICI 182,780 and tamoxifen on steady state levels of complement $\mathrm{C} 3$ and clusterin mRNAs in vivo}

The expression of complement C3 in the primary tumor requires estradiol, and was repressed in ovariectomized females and in intact females treated with ICI 182,780. Tamoxifen, however, did not repress the expression of clusterin in intact females, and displayed partial agonist activity in ovariectomized females (Fig. 3A). The agonistic action of tamoxifen on the expression of clusterin was even more evident, since tamoxifen up-regulated clusterin mRNA levels in primary tumors almost as effectively as estradiol, while the ability of ICI 182,780 to repress the expression of clusterin appeared to be significantly compromised (Fig. 3B). The expression of clusterin was further up-regulated in the metastatic cells from the ipsilateral lymph nodes in animals treated with tamoxifen (Fig. 3C). In both the primary tumor and the lymph nodes, the level of expression of clusterin was elevated above that seen in the intact cycling animals.

\section{Effect of estradiol, ICI 182,780 and tamoxifen on clusterin levels in vivo}

Using the $\alpha$-chain specific antibody, 7A8 (Lakins et al. 1998), to detect the mature form of clusterin revealed that the expression of the protein in the primary tumors 

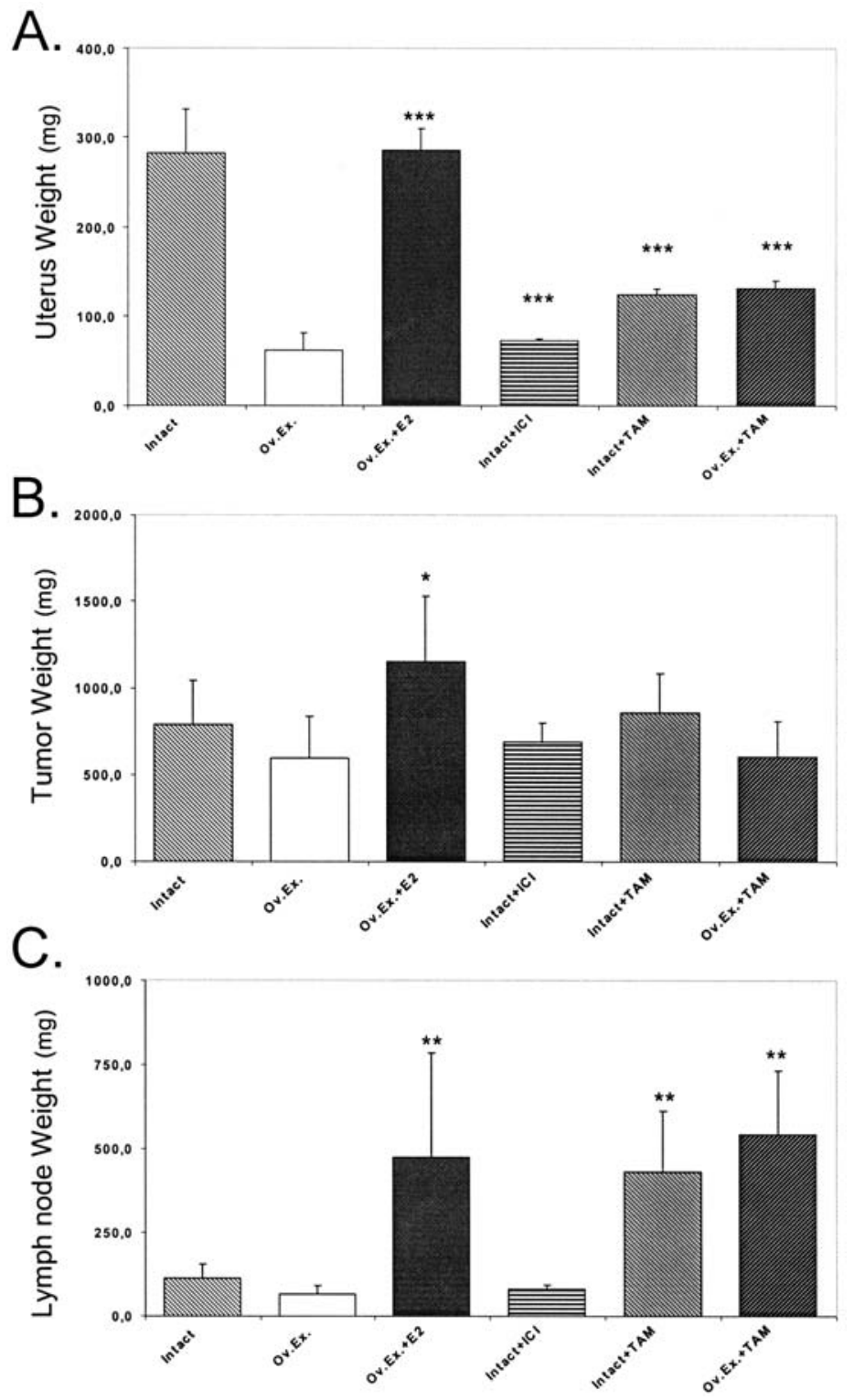

Figure 2 Effect of estradiol, ICl-182,780 and tamoxifen on (A) uterine weight, (B) primary tumor weight and (C) ipsilateral lymph node weight in intact and ovariectomized syngeneic DA/Han rats. Ov.Ex., ovariectomized animals; Ov.Ex.+E2, ovariectomized animals supplemented with estradiol undecyclate $(50 \mu \mathrm{g} / \mathrm{rat})$; Intact $+\mathrm{ICl}$, intact animals injected daily with $5 \mathrm{mg} / \mathrm{kg} \mathrm{per} \mathrm{day} \mathrm{ICl}$ 182,780; Intact+TAM, intact animals injected daily with $20 \mathrm{mg} / \mathrm{kg}$ per day tamoxifen; Ov.Ex.+TAM, ovariectomized animals injected daily with $20 \mathrm{mg} / \mathrm{kg}$ per day tamoxifen. ${ }^{*} P \leq 0.05 ;{ }^{* *} P \leq 0.01$; ${ }^{* * *} P \leq 0.001$, treatment groups were compared with the corresponding intact or ovariectomized controls.

reflects the changes in the mRNA levels. Clusterin expression was low in the cycling rats, and was repressed in the tumors of ovariectomized animals and in intact animals treated with ICI 182,780. Tamoxifen significantly up-regulated the expression of the protein in the primary tumors in both intact and ovariectomized females treated with tamoxifen (Fig. 4A). A similar expression profile was seen in the lymph node deposits, where it is clear that tamoxifen exerted very significant agonist activity (Fig. 4B).

In summary, these data demonstrated that while tamoxifen exerts an antagonistic effect on the uterus, in this preclinical model of endometrial cancer the SERM exerted significant agonist activity which was further enhanced in the lymph node metastases, where it appeared to have a significant trophic effect on the size of the 
A.

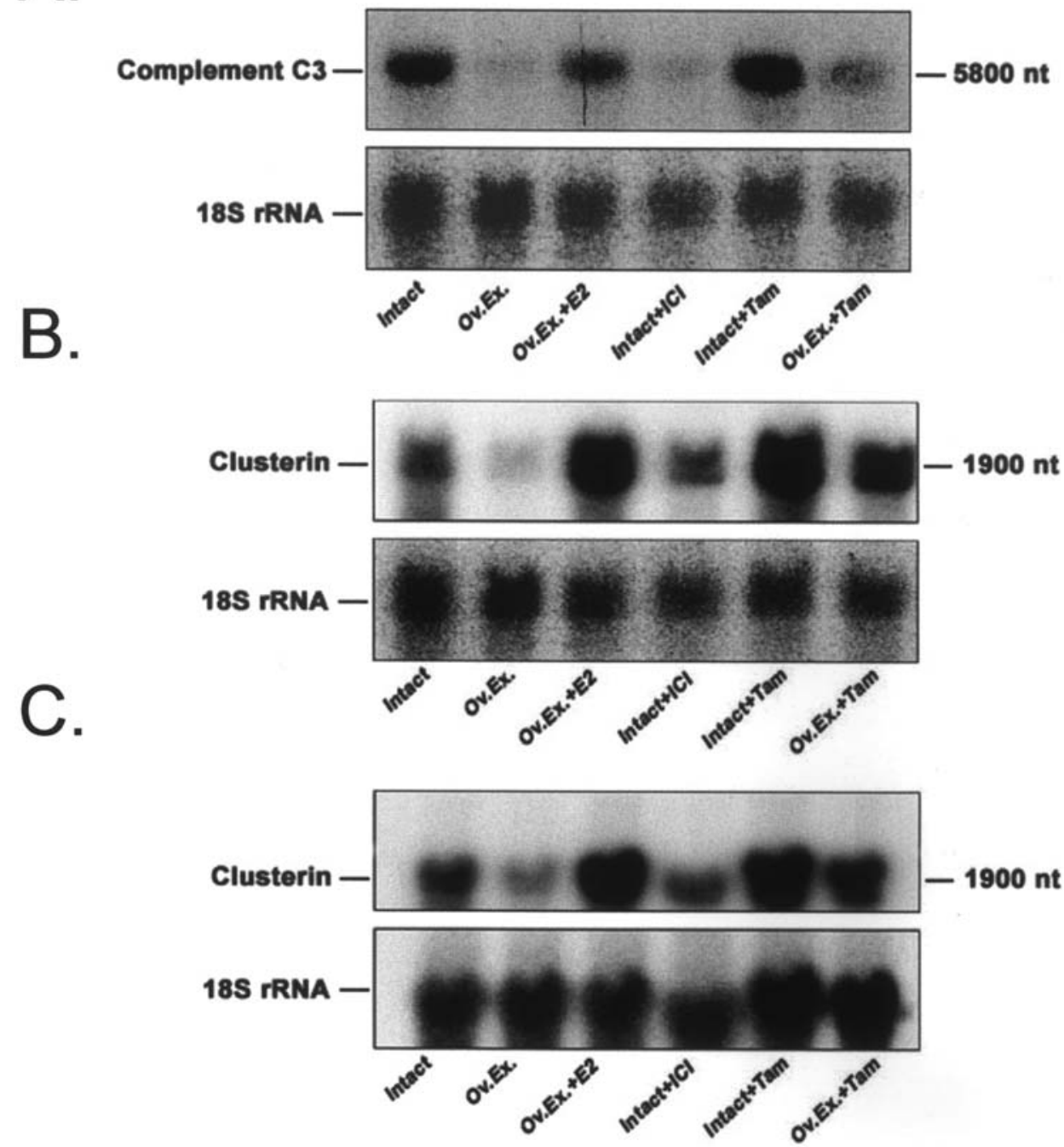

Figure 3 Effect of estradiol, ICl 182,780 and tamoxifen on steady state levels of (A) complement $C$ and (B) clusterin mRNA in primary tumors and $(\mathrm{C})$ clusterin mRNA steady state levels in ipsilateral lymph node metastases. Total RNA was extracted from primary tumors and lymph node metastases, electrophoresed and hybridized as outlined in Materials and Methods. Abbreviations are defined in Fig. 2.

metastatic tumors. This is in marked contrast to the effects of the pure anti-estrogen ICI 182,780 which maintained its antagonistic activity in the uterus, primary tumor and lymph node metastases.

\section{Discussion}

Several retrospective studies have suggested that postmenopausal women on hormone replacement therapy have a slightly elevated risk for endometrial cancer, and postmenopausal women taking tamoxifen for the treatment of breast cancer or as a chemopreventive strategy for breast cancer also have an elevated risk for endometrial cancer. Using the RUCA-I xenograft in cycling animals as a preclinical model for premenopausal disease and in ovariectomized animals to model postmenopausal disease, we have demonstrated that tamoxifen exerts very significant agonist effects, particularly on the growth of the lymph node metastases. These observations have demonstrated that while the growth of the primary tumor is only moderately affected by tamoxifen, the expression of clusterin is markedly up-regulated in RUCA-I tumors grown in either cycling or ovariectomized female DA/Han rats, and in the lymph node metastases the expression of clusterin is markedly up-regulated in both cycling and ovariectomized hosts with a corresponding increase in 


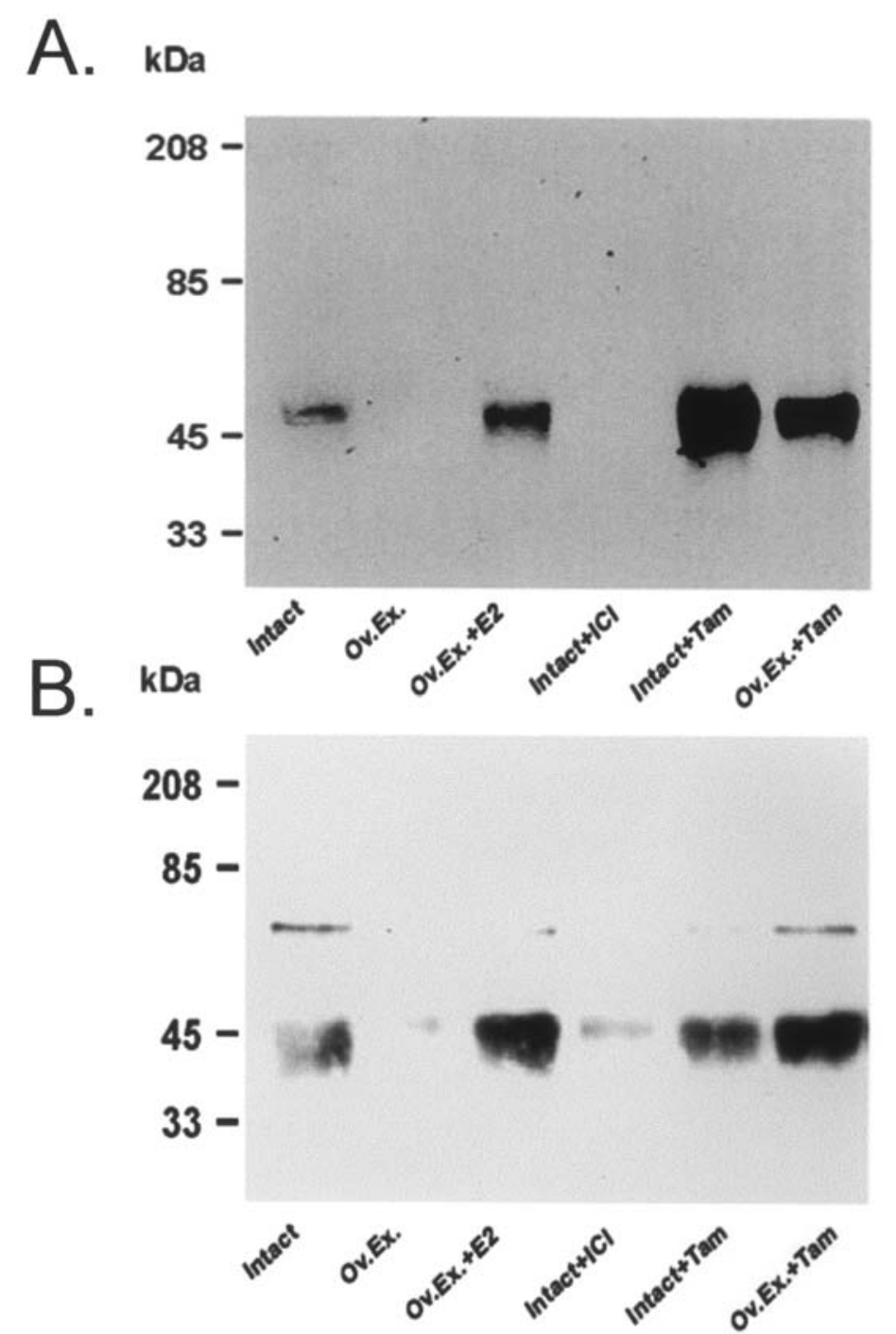

Figure 4 Effect of estradiol, ICl 182,780 and tamoxifen on clusterin in (A) primary tumors and (B) ipsilateral lymph node metastases. Cell lysates were prepared as outlined in Materials and Methods. Total protein $(50 \mu \mathrm{g})$ was electrophoresed, Western blotted and probed with the 7A8 monoclonal anti-clusterin antibody. Abbreviations are defined in Fig. 2.

tumor size. These findings are in marked contrast to the effects of ICI 182,780, which displays little activity in the primary tumor but is clearly a powerful antagonist of the growth of the lymph node metastases and of clusterin expression.

Clusterin was originally identified as a protein secreted by the Sertoli cells of the testes and isolated from rete testes fluid which induced clustering of heterologous cell types (Blaschuk et al. 1983, Collard \& Griswold 1987). The $2 \mathrm{~kb}$ mRNA coding for this protein has been shown to be induced during regression of several hormone-dependent tissues, including the prostate, breast and endometrium (Tenniswood et al. 1998). The role of the protein in cell death has remained elusive, although the secreted isoform of the protein clearly acts as an acid activatable, extracellular chaperone (Carver et al. 2002). Recent studies have shown that clusterin expression correlates with tumor grade and resistance to cytotoxic compounds in prostate cancer (Bettuzzi et al. 2000) and in one retrospective study has been associated with progression to a metastatic phenotype in breast cancer (Redondo et al. 2000). Recent studies have also demonstrated that forced over-expression of clusterin confers a survival advantage and accelerates metastatic progression in preclinical models of prostate and breast cancer (Whyte et al. 2004). It was not possible to determine in this model system whether the increase in the size of the metastatic deposits in the lymph nodes of the animals treated with 
tamoxifen was due to an increase in proliferation once the cells had reached the metastatic site or whether the tamoxifen treatment increased the number of cells released into the lymphatic drainage from the primary tumor. Nevertheless, taken together, these data suggest that, particularly in postmenopausal women, tamoxifen acts as an agonist during tumor promotion and metastatic progression, probably through the induction of clusterin expression.

\section{Acknowledgements}

This work was supported by operating grants from the Deutsches Forschungsgemeinschaft, NATO and the Coleman Foundation. D McD was supported by the National Consortium for Graduate Degrees for Minorities in Engineering and Science.

\section{References}

Bettuzzi S, Davalli P, Astancolle S, Carani C, Madeo B, Tampieri A, Corti A, Saverio B, Pierpaola D, Serenella A, Cesare C, Bruno M, Auro T \& Arnaldo C 2000 Tumor progression is accompanied by significant changes in the levels of expression of polyamine metabolism regulatory genes and clusterin (sulfated glycoprotein 2) in human prostate cancer specimens. Cancer Research 60 28-34.

Blaschuk O, Burdzy K \& Fritz IB 1983 Purification and characterization of a cell-aggregating factor (clusterin), the major glycoprotein in ram rete testis fluid. Journal of Biological Chemistry 258 7714-7720.

Carver JA, Rekas A, Thorn DC \& Wilson MR 2003 Small heatshock proteins and clusterin: intra- and extracellular molecular chaperones with a common mechanism of action and function? Journal of the International Union of Biochemistry and Molecular Biology 55 661-668.

Chirgwin JM, Przybyla AE, MacDonald RJ \& Rutter WJ 1979 Isolation of biologically active ribonucleic acid from sources enriched in ribonuclease. Biochemistry 18 5294-5299.

Chlebowski RT, Col N, Winer EP, Collyar DE, Cummings SR, Vogel VG 3rd, Burstein HJ, Eisen A, Lipkus I \& Pfister DG 2002 American Society of Clinical Oncology technology assessment of pharmacologic interventions for breast cancer risk reduction including tamoxifen, raloxifene, and aromatase inhibition. Journal of Clinical Oncology 20 3328-3343.

Collard MW \& Griswold MD 1987 Biosynthesis and molecular cloning of sulfated glycoprotein 2 secreted by rat Sertoli cells. Biochemistry 26 3297-3303.

Flototto T, Djahansouzi S, Glaser M, Hanstein B, Niederacher D, Brumm C \& Beckmann MW 2001 Hormones and hormone antagonists: mechanisms of action in carcinogenesis of endometrial and breast cancer. Hormone and Metabolic Research 33 451-457.

Heikaus S, Winterhager E, Traub O \& Grummer R 2002 Responsiveness of endometrial genes Connexin26, Connexin43, C3 and clusterin to primary estrogen, selective estrogen receptor modulators, phyto- and xenoestrogens. Journal of Molecular Endocrinology 29 239-249.

Horn DW, Vollmer G, von Angerer E \& Schneider MR 1994 Effect of the nonsteroidal antiestrogen ZK 119.010 on growth and metastasis of the EnDA endometrial carcinoma. International Journal of Cancer 58 426-429.

Lakins J, Bennett SA, Chen JH, Arnold JM, Morrissey C, Wang P, O'Sullivan J \& Tenniswood M 1998 Clusterin biogenesis is altered during apoptosis in the regressing rat ventral prostate. Journal of Biological Chemistry 273 27887-27895.

Lupulescu A 1993 Estrogen use and cancer risk: a review. Experimental and Clinical Endocrinology 101 204-214.

Lupulescu A 1995 Estrogen use and cancer incidence: a review. Cancer Investigation 13 287-295.

Redondo M, Villar E, Torres-Munoz J, Tellez T, Morell M \& Petito CK 2000 Overexpression of clusterin in human breast carcinoma. American Journal of Pathology 157 393-399.

Salvesen HB \& Akslen LA 2002 Molecular pathogenesis and prognostic factors in endometrial carcinoma. APMIS 110 673-689.

Schutze N, Kraft V, Deerberg F, Winking H, Meitinger D, Ebert K, Knuppen R \& Vollmer G 1992 Functions of estrogens and anti-estrogens in the rat endometrial adenocarcinoma cell lines RUCA-I and RUCA-II. International Journal of Cancer 52 941-949.

Tenniswood M, Wang Z, Lakins J, Morrissey C, O'Sullivan J \& Tang H 1998 Clusterin in the male reproductive tract. Journal of Andrology 19 508-516.

The Practice Committee of the American Society of Reproductive Medicine 2004 Estrogen and progestogen therapy in post menopausal women. Fertility and Sterility 81 231-241.

Vollmer G \& Schneider MR 1996 The rat endometrial adenocarcinoma cell line RUCA-I: a novel hormoneresponsive in vivo/in vitro tumor model. Journal of Steroid Biochemistry and Molecular Biology 58 103-115.

Wakeling AE, Dukes M \& Bowler J 1991 A potent specific pure antiestrogen with clinical potential. Cancer Research $\mathbf{5 1}$ 3867-3873.

Whyte L, Flanagan L, Dawson J, Ryan A, Lopez J \& Tenniswood MP 2004 Clusterin overexpression confers resistance to cytotoxic drugs and triggers metastatic progression in breast cancer cells. 18th Meeting European Association of Cancer Research. European Journal of Cancer 18181.

Wunsche W, Tenniswood MP, Schneider MR \& Vollmer G 1998 Estrogenic regulation of clusterin mRNA in normal and malignant endometrial tissue. International Journal of Cancer 76 684-688. 